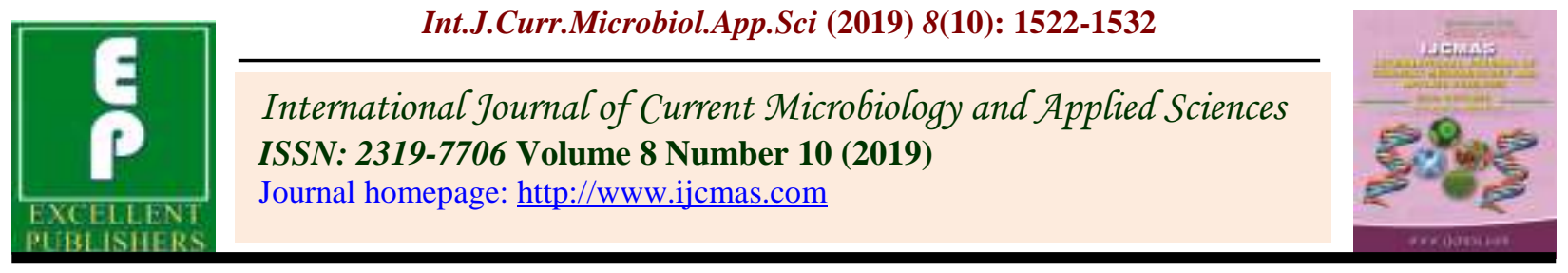

Original Research Article

https://doi.org/10.20546/ijcmas.2019.810.177

\title{
Response of Nutrient Omission on Growth, Productivity and Profitability of Maize (Zea mays)-Wheat (Triticum aestvum L) Cropping System in Southern Rajasthan
}

\author{
Hargilas* \\ Agricultural Research Station, Maharana Pratap University of Agriculture \& Technology, \\ Banswara - 327 001, Rajasthan \\ *Corresponding author
}

\section{A B S T R A C T}

Keywords

Omission, Nutrient, Productivity,

Profitability, Maize, Wheat

Article Info

Accepted:

12 September 2019

Available Online:

10 October 2019
A field experiment was conducted at Agricultural Research Station (MPUAT), Banswara (Rajasthan), India to assess the validation of SSNM practice in maizewheat cropping system under sub-humid condition of southern Rajasthan. The experiment comprised seven treatments of absolute control (No nutrient), RDF-state, RDF-national, SSNM, SSNM-N, SSNM-P and SSNM-K. Treatments were applied in randomized block design with three replication at fixed site for both crops during both the years. Growth and yield attributes significantly influenced by nutrient omission treatments and their values were higher at nutrients that applied through SSNM approach. The target yield based SSNM nutrient management approach significantly increased grain yield by $32.43 \%$ of maize, $14.69 \%$ of wheat and $12.46 \%$ of system productivity over RDF, respectively. Omission of $\mathrm{N}$ and $\mathrm{P}$ resulted in 50 and $17.4 \%$ reduction the grain yield, respectively. The yield reduction was slightly lower with $\mathrm{K}$ omission compared to SSNM-N and SSNM-P. The SSNM based NPK application was resulted in consistently higher gross returns of Rs 1, 48,547 and net return of Rs 1, 04,387 and B:C ratio of 2.36 of the maize-wheat cropping system. Overall, the results revealed that omitting $\mathrm{N}$ and $\mathrm{P}$ leads to significant yield penalty and application of nutrient using SSNM approach should adopted for achieving higher yield and profitability of maize-wheat cropping system.

\section{Introduction}

Maize (Zea mays L.)-wheat (Triticum aestivum L.) is a pre-dominant cropping system in India that covers $1.8 \mathrm{~m}$ ha area to contribute about $3 \%$ in national food. The productivity of this cropping system is limited by genotypes and crop established techniques. Maize yield is low in Southern Rajasthan due to cultivated low yielding genotypes with imbalanced nutrient application as well as unfertilized area. The maize area about 15$45 \%$ in the country is remaining under imbalanced nutrient availability as well as 
unfertilized (Jat et al., 2011). Amongst various agricultural inputs, fertilizers contribute about 30-50\% towards yield performance (Stewart 2002). By introduction of single cross hybrids in maize, productivity increased up to $7.0 \mathrm{t} / \mathrm{ha}$ and total nutrient removal has increased to 420 $\mathrm{kg} / \mathrm{ha}$ (Jat et al., 2013). Low fertilizer efficiency, inadequacy of current fertilizer recommendations, and the exclusion of nutrients other than $\mathrm{N}, \mathrm{P}$ and $\mathrm{K}$ from the recommended/balanced nutrient dose and continuously deteriorating soil quality. Nutrients available in soil are rarely present in adequate amount and imbalanced proportion to meet the nutrient requirement of the crops. However, growing awareness about impaired soil health, declining or stagnating productivity growth and decreasing nutrientuse efficiency (NUE) are compelling the farmers to use higher levels of fertilizers, mostly $\mathrm{N}$ and $\mathrm{P}$ fertilizers, particularly during last two decades leading to over mining of other major, secondary and micro-nutrients (Dass et al., 2014). Eventually, the recovery efficiency of fertilizer nutrients is about 20$40 \%, 15-20 \%$ and $40-50 \%$ for $\mathrm{N}, \mathrm{P}$ and $\mathrm{K}$, respectively while for secondary and micronutrients, it is very low ranging between 5-12\% (Rao, 2014). Therefore, adopting the SSNM-NE concept has shown improvement in yields by estimations of crop need-based nutrient-supplying capacity as per target yield. This considers indigenous nutrient supply of soil and productivity targets capable to sustained yields and assured restoration of soil fertility. International Plant Nutrition Institute (IPNI) in collaboration with CIMMYT has recently developed a Nutrient Expert (NE), a nutrient decision support system, based on SSNM principles. NE provides fertilizer recommendations by considering yield responses and targeted agronomic efficiencies along with contribution of nutrients from indigenous sources. This systematic approach of capturing site-specific information that is important for developing a location-specific- recommendation. It also helps in providing information about prevailing climatic conditions affecting nutrient management under specific-location and right rate of nutrients to meet attainable yield goals. Considering above views, the current study was made to recognize the effects of blanket recommendations as well as omitted nutrients on growth, productivity and profitability of maize and wheat and to develop SSNM for maize-wheat cropping under humid condition of Southern Rajasthan.

\section{Materials and Methods}

A field experiment was conducted at agricultural research station (MPUAT), Banswara during two consecutive years of 2008-09 to 2009-10 to find out the response of nutrient expert (NE) in the based on decision support system to achieve targeted yield of maize (Zea mays L.) and wheat under maizewheat cropping system. The experimental field is geographically situated at $23^{\circ} 33^{\prime} \mathrm{N}$ latitude, $74^{\circ} 27^{\prime} \mathrm{E}$ longitude and altitude of 220 $M$ above Mean Sea Level covered under humid southern plain agro-climatic zone of Rajasthan, which falls under sub-humid climate with dry, hot summer and mild winters. The average annual rainfall is about $862 \mathrm{~mm}$ that is more than $80 \%$ generally received during the monsoon season (JuneOctober). The soil of experimental field was clay loam in texture with the slightly alkaline in reaction $(7.9 \mathrm{pH})$ of the top $15 \mathrm{~cm}$ layer of soil. Soil had low organic carbon (0.33), low available nitrogen (218 kg/ha), medium available phosphorus (26 kg/ha) and high available potassium $(398 \mathrm{~kg} / \mathrm{ha})$. The experiment comprised seven treatments viz. absolute control $\left(\mathrm{T}_{1}\right)$, state $\mathrm{RDF}\left(\mathrm{T}_{2}\right)$, national $\operatorname{RDF}\left(\mathrm{T}_{3}\right)$, Site Specific Nutrient Management (SSNM) $\left(\mathrm{T}_{4}\right)$, SSNM-N ( $\left.\mathrm{T}_{5}\right)$, SSNM-P $\left(\mathrm{T}_{6}\right)$ and SSNM-K $\left(\mathrm{T}_{7}\right)$ in randomized block design (RBD) with three replication. The SSNM-NE approach, for fertilizer NPK requirements are 
calculated based on given information of specific field and ecology that formulating by the relationship between nutrients uptake at give at harvest and grain yield i.e. internal nutrient efficiency is predicted by using the QUEFTS (Quantitative evaluation of the fertility of tropical soil) model (Satyanarayan et al., 2013). Treatment details are mentioned in Table 1 for maize and wheat crops.

The fertilizers of $\mathrm{N}, \mathrm{P}, \mathrm{K}$ and $\mathrm{Zn}$ were used as prilled urea $(46 \% \mathrm{~N})$, single super phosphate $\left(16 \% \mathrm{P}_{2} \mathrm{O}_{5}\right)$, muriate of potash $\left(60 \% \mathrm{~K}_{2} \mathrm{O}\right)$ and zinc sulphate $\left(\mathrm{ZnSO}_{4} .7 \mathrm{H}_{2} \mathrm{O}\right)$, respectively. In case of maize, full dose of $\mathrm{P}, \mathrm{K}$ and $\mathrm{Zn}$ and $1 / 3^{\text {rd }}$ dose of $N$ were applied at the time of sowing and remaining $2 / 3^{\text {rd }}$ dose of $\mathrm{N}$ was applied in two equal splits at knee high and before tasseling stage.

In case of wheat, full doses of $\mathrm{P}$ and $\mathrm{K}$ and $1 / 2^{\text {nd }}$ dose of $N$ were applied at the time of sowing and remaining $1 / 2^{\text {nd }}$ dose of $\mathrm{N}$ was applied as top dressing after first irrigation at crown root initiation (CRI) stage. Maize variety HQPM 1 was manual dribbled at $60 \times 25 \mathrm{~cm}$ spacing in rows with a seed rate of $20 \mathrm{~kg} / \mathrm{ha}$ in first week of July and harvested in October during both the years. Wheat variety PBW 343 was sown in line $22.5 \mathrm{~cm}$ apart with seed rate of $100 \mathrm{~kg} / \mathrm{ha}$ in the second week of November and harvested in the first week of April. Uniform cultural operations and plant protection measures were adopted in all the treatments. Growth and yield attributes were recorded as mean of 10 observations of the crop. Maize was harvested at cob maturity and cobs were picked manually, air dried and threshed by maize seller. Wheat crop was harvested manually and threshed using mini thresher. Grain yield of maize and wheat were reported $15 \%$ grain moisture. The economic analysis was done considering on local rate market rate of inputs and output in respective year. Statistical analysis of the data was carried out using analysis of variation technique as applicable to RBD (Gomez and Gomez, 1984).

\section{Results and Discussion}

\section{Growth parameters of maize}

The maximum CGR for 0-30 and 60-90 days intervals obtained in site-specific nutrient management (SSNM) practice followed by SSNM-K (Table 1) and it was significantly superior over rest treatments, whereas, CGR for 30-60 days interval was also recorded highest with SSNM practice followed by SSNM-K and SSNM-P and significantly higher than rest treatments. The adequate availability of nutrients under SSNM practice to maize crop might have increased the number of functional leaves, which, in turn, enhanced the crop growth rate and dry matter accumulation. The highest plant height (210 $\mathrm{cm}$ ) at harvest (Table 2) recorded under SSNM practice followed by SSNM-K and it was significantly superior over rest treatments. The higher plant height under SSNM practice might be due to balanced and sufficient availability of nutrients to plant during the crop growth and development period for accumulation of dry matter which, in turn to be enhanced plant height. The higher growth under SSNM practice might be due to balanced and sufficient availability of nutrients to plant during the crop growth and development period. The crop growth rate and plant height increased under SSNM by 7.67, 10.20 and $27.36 \%$ faster crop growth rate compared to SSNM-P, national-RDF and SSNM-N, respectively, similarly, 13.70, 19.30, and $33.48 \%$ higher plant height under SSNM compared to SSNM-P, national RDF and SSNM-N, respectively. Similar, findings recorded by Hargilas et al., (2017).Omission of phosphorus recorded as lesser crop growthlimiting factor compared to lower dose of nitrogen in RDF and omission of nitrogen $(\mathrm{SSNM}-\mathrm{N})$, respectively. It has proved that 
nitrogen is a most plant growth-limiting factor among all nutrients (Hargilas, 2016). The SSNM provides an approach to "feeding" crops with nutrients as and when they are needed (Satyanarayana et al., 2012).

\section{Yield attributes of maize}

The yield attributes of maize (cobs/plant, grains/cob, shelling and test weight) were significantly influenced by nutrient management treatments (Table 2). Sitespecific nutrient management (SSNM) recorded significantly higher no of cobs/plant, grains/cob, shelling percent, test weight. The maximum cobs/plant was recorded under SSNM followed by SSNM-K and it was 38, $83,140,175$, and $207 \%$ significantly superior over national-RDF, state-RDF, SSNM-P, SSNM-N, and absolute control, respectively. The maximum number of grains/cob (553) recorded in SSNM followed by SSNM-K and significantly higher superior over rest treatments. The maximum shelling percentage $(83.45 \%)$ recorded in SSNM followed by SSNM-K and significantly higher over rest treatments. The highest test weight $(307.67 \mathrm{~g})$ recorded in SSNM followed by SSNM-K, SSNM-P and national-RDF, but it was significantly higher over state-RDF, SSNM-N and absolute control. All yield attributes were highly influenced by omission of nitrogen compared to omission of phosphorus. Whereas, omission of $\mathrm{K}$ have negligible role in yield attributes. It might be due to lower availability of nitrogen and higher availability of potash in experimental soil. These similar findings reported by Hargilas et al., (2017).

\section{Growth parameters of wheat}

The site-specific nutrient management (SSNM) approach based target yield of crop in the cropping system with soil status under agro-ecological system resulted in significantly higher crop growth rate, plant height and yield attributes of wheat (Table 3). The higher plant height under SSNM practice might be due to balanced and sufficient availability of nutrients to plant during the crop growth and development period for accumulation of dry matter which, in turn to be enhanced plant height. The higher growth under SSNM practice might be due to adequate nutrient availability to plant during the crop growth and development period.

The maximum crop growth rate (2.50) at 0-30 days interval under SSNM followed by SSNM-K and significantly superior over rest treatments. However, CGR at 30-60 days interval under SSNM was recorded highest (6.67) followed by SSNM-K and nationalRDF and significantly superior over rest treatments. The CGR was also recorded highest (14.61) at 60-90 days interval under SSNM followed by SSNM-K and significantly superior over rest treatments. The higher crop growth rate under SSNM approach based fertilization might be due to balanced and sufficient availability of nutrients to plant during the crop growth and development period. The CGR was 58, 86 and 56\% higher in SSNM compared to omission of nitrogen at 0-30, 30-60 and 60-90 days intervals, respectively. Therefore, it has cleared that nitrogen is major growth limiting factor in wheat crop. The highest plant height $(89.4 \mathrm{~cm})$ at harvest under SSNM followed by SSNM-K and significantly superior over rest treatments.

Omission of phosphorus recorded as lesser crop growth-limiting factor compared to lower dose of nitrogen in RDF and omission of nitrogen (SSNM-N), respectively. It has proved that nitrogen is a most plant growthlimiting factor among all nutrients. Sapkota et al., (2014) reported that required nutrients were applied at adequate and proper ratio based on crop needs, which ultimately led to higher crop growth under SSNM. 


\section{Yield attributes of wheat}

The yield attributes of wheat (ears $/ \mathrm{m}^{2}$, grains/ear and test weight) were significantly influenced by nutrient management treatments (Table 3). Site-specific nutrient management (SSNM) recorded significantly higher no of ears $/ \mathrm{m}^{2}$, grains/ear and test weight. The maximum ears $/ \mathrm{m}^{2}$ was recorded under SSNM followed by SSNM-K and it was 17.42, 20.01, $24.18, \quad 36.33$ and $50.68 \%$ significantly superior over national-RDF, state-RDF, SSNM-P, SSNM-N, and absolute control, respectively. The maximum number of grains/ear (50.91) recorded in SSNM followed by SSNM-K and significantly higher superior over rest treatments. The highest test weight (46.33g) recorded in SSNM followed by SSNM-K, SSNM-P and national-RDF and state-RDF, but it was 44.42 and $79.71 \%$ significantly higher over SSNM-N and absolute control. All yield attributes were highly influenced by omission of nitrogen compared to omission of phosphorus. Whereas, omission of $\mathrm{K}$ have negligible role in yield attributes might be due to sufficient availability of $\mathrm{K}$ in experimental soil. The highest values of growth parameters with SSNM approach translated into better yield attributes. Probably due to more absorption and utilization of available nutrients leading to overall improvement of crop growth and source-sink relationship, which in turn increased the yield attributes under SSNM. Similar findings reported by Jat et al., (2018).

\section{Yield of system}

The yield was affected directly to effect of omitted nutrients on yield attributes (Table 4). The highest yield of maize (58.85 q/ha) under SSNM practice that was significantly superior to tune of $120.66,89.17,55.77,32.43$ and $11.73 \%$ over absolute control, SSNM-N, SSNM-P, state RDF and national RDF, respectively. Similarly, maximum yield of wheat $(55.51 \mathrm{q} / \mathrm{ha})$ recorded in SSNM followed by SSNM-K and it was 93.82, 55.75, $27.43,14.69$ and $12.87 \%$ significantly higher over absolute control, SSNM-N, SSNM-P, state-RDF and national-RDF, respectively. The maximum maize equivalent yield (123.79 $\mathrm{q} / \mathrm{ha}$ ) was recorded under SSNM which was found at par with SSNM-K and significantly superior to tune of 105.70, 69.99, 39.50, 22.46 and $12.33 \%$ over absolute control, SSNM-N, SSNM-P, state-RDF and national-RDF, respectively. The effect of omitted nutrients on yield attributes reflected directly in the grain yield of both the crops and maize equivalent yield of the system was affected to yield of both crops.

Table.1 Treatment details for maize-wheat crops

\begin{tabular}{|c|c|c|}
\hline Treatment & $\begin{array}{c}\text { Maize } \\
\left(\mathrm{N}: \mathrm{P}_{2} \mathrm{O}_{5}: \mathrm{K}_{2} \mathrm{O}: \mathrm{ZnSO}_{4}\right)\end{array}$ & $\begin{array}{c}\text { Wheat } \\
\left(\mathrm{N}: \mathbf{P}_{2} \mathrm{O}_{5}: \mathrm{K}_{2} \mathrm{O}\right)\end{array}$ \\
\hline $\mathrm{T}_{1}$ : Absolute control & (00:00:00:00 kg/ha) & (00:00:00 kg/ha) \\
\hline$T_{2}:$ State-RDF & $(90: 40: 30: 00 \mathrm{~kg} / \mathrm{ha})$ & $(120: 60: 40 \mathrm{~kg} / \mathrm{ha})$ \\
\hline$T_{3}$ : National-RDF & $(120: 60: 40: 25 \mathrm{~kg} / \mathrm{ha})$ & $(120: 60: 40 \mathrm{~kg} / \mathrm{ha})$ \\
\hline $\mathrm{T}_{4}: \mathrm{SSNM}$ & $(229: 72: 00: 25 \mathrm{~kg} / \mathrm{ha})$ & $(180: 36: 00 \mathrm{~kg} / \mathrm{ha})$ \\
\hline$T_{5}:$ SSNM-N & $(00: 72: 00: 25 \mathrm{~kg} / \mathrm{ha})$ & $(00: 36: 00 \mathrm{~kg} / \mathrm{ha})$ \\
\hline$T_{6}:$ SSNM-P & $(229: 00: 00: 25 \mathrm{~kg} / \mathrm{ha})$ & $(180: 00: 00 \mathrm{~kg} / \mathrm{ha})$ \\
\hline $\mathrm{T}_{7}: \mathrm{SSNM}-\mathrm{K}$ & $(229: 72: 00: 25 \mathrm{~kg} / \mathrm{ha})$ & $(180: 00: 00 \mathrm{~kg} / \mathrm{ha})$ \\
\hline
\end{tabular}


Table.2 Effect of site-specific nutrient management on growth and yield attributes of maize

\begin{tabular}{|c|c|c|c|c|c|c|c|c|}
\hline Treatment & $\begin{array}{c}\text { Plant height } \\
\text { (cm) }\end{array}$ & $\begin{array}{c}\text { CGR } \\
\text { 0-30 DAS }\end{array}$ & $\begin{array}{c}\text { CGR } \\
\text { 30-60 DAS }\end{array}$ & $\begin{array}{c}\text { CGR } \\
\text { 60-90 DAS }\end{array}$ & Cobs/plant & Grains/cob & $\begin{array}{c}\text { Shelling } \\
(\%)\end{array}$ & $\begin{array}{c}\text { Test weight } \\
\text { (g) }\end{array}$ \\
\hline$T_{1}$ : Control & 155.55 & 0.63 & 1.11 & 5.58 & 0.69 & 335 & 59.66 & 243.33 \\
\hline$T_{2}:$ State-RDF & 173.88 & 0.94 & 1.66 & 7.49 & 1.16 & 450 & 72.50 & 260.00 \\
\hline$T_{4}:$ SSNM & 210.00 & 1.27 & 2.29 & 9.21 & 2.12 & 553 & 83.45 & 307.67 \\
\hline $\mathrm{T}_{5}: \mathrm{SSNM}-\mathrm{N}$ & 164.89 & 0.71 & 1.36 & 6.90 & 0.77 & 414 & 61.75 & 251.00 \\
\hline $\mathrm{CD}(\mathrm{p}=\mathbf{0 . 0 5})$ & 10.63 & 0.11 & 0.26 & 0.97 & 0.27 & 58.28 & 5.12 & 31.28 \\
\hline
\end{tabular}

Table.3 Effect of site-specific nutrient management on growth and yield attributes of wheat

\begin{tabular}{|c|c|c|c|c|c|c|c|}
\hline Treatment & $\begin{array}{c}\text { CGR } \\
\text { 0-30 DAS }\end{array}$ & $\begin{array}{c}\text { CGR } \\
\text { 30-60 DAS }\end{array}$ & $\begin{array}{c}\text { CGR } \\
\text { 60-90 DAS }\end{array}$ & $\begin{array}{c}\text { Plant height } \\
\text { (cm) }\end{array}$ & Earhead $/ \mathrm{m}^{2}$ & Grains/earhead & $\begin{array}{c}\text { Test } \\
\text { weight } \\
\text { (g) }\end{array}$ \\
\hline $\mathbf{T}_{1}$ : Control & 1.30 & 3.61 & 7.54 & 47.0 & 352.44 & 26.35 & 25.78 \\
\hline $\mathrm{T}_{2}:$ State-RDF & 2.16 & 6.30 & 12.74 & 72.7 & 442.52 & 41.33 & 42.45 \\
\hline $\mathbf{T}_{3}:$ National-RDF & 2.25 & 6.93 & 12.94 & 79.3 & 452.26 & 44.00 & 42.91 \\
\hline $\mathbf{T}_{4}: \mathbf{S S N M}$ & 2.50 & 7.67 & 14.61 & 89.4 & 531.06 & 50.91 & 46.33 \\
\hline $\mathrm{T}_{5}: \mathrm{SSNM}-\mathbf{N}$ & 1.59 & 4.13 & 9.38 & 58.5 & 389.53 & 32.79 & 32.08 \\
\hline T6: SSNM-P & 1.95 & 5.85 & 11.46 & 71.4 & 427.66 & 40.07 & 39.20 \\
\hline $\mathrm{T}_{7}: \mathrm{SSNM}-\mathrm{K}$ & 2.51 & 7.65 & 14.56 & 87.4 & 528.90 & 50.51 & 46.33 \\
\hline$C D(p=0.05)$ & 0.17 & 1.07 & 1.3 & 6.92 & 60.37 & 7.51 & 6.82 \\
\hline
\end{tabular}


Table.4 Effect of site-specific nutrient management on yield and economics of maize-wheat cropping system

\begin{tabular}{|c|c|c|c|c|c|c|}
\hline Treatment & $\begin{array}{l}\text { Seed yield of } \\
\text { maize (q/ha) }\end{array}$ & $\begin{array}{c}\text { Grain yield of } \\
\text { wheat (q/ha) }\end{array}$ & $\begin{array}{c}\text { MEY of } \\
\text { cropping } \\
\text { system (q/ha) }\end{array}$ & $\begin{array}{l}\text { Gross return } \\
\text { (Rs/ha) }\end{array}$ & $\begin{array}{l}\text { Net return } \\
\text { (Rs/ha) }\end{array}$ & B:C ratio \\
\hline $\mathrm{T}_{1}$ : Control & 26.67 & 28.64 & 60.18 & 72215 & 39321 & 1.20 \\
\hline$T_{2}:$ State-RDF & 44.44 & 48.40 & 101.07 & 121281 & 78570 & 1.84 \\
\hline$T_{3}:$ National-RDF & 52.67 & 49.18 & 110.20 & 132246 & 86949 & 1.92 \\
\hline $\mathrm{T}_{4}: \mathrm{SSNM}$ & 58.85 & 55.51 & 123.79 & 148547 & 104387 & 2.36 \\
\hline $\mathrm{T}_{5}: \mathrm{SSNM}-\mathrm{N}$ & 31.11 & 35.64 & 72.82 & 87378 & 47914 & 1.21 \\
\hline $\mathrm{T}_{6}:$ SSNM-P & 37.78 & 43.56 & 88.74 & 106485 & 67677 & 1.74 \\
\hline T $_{7}:$ SSNM-K & 56.22 & 55.33 & 120.96 & 145152 & 100992 & 2.29 \\
\hline CD $(p=0.05)$ & 5.75 & 4.92 & 10.08 & 12107 & 12107 & 0.30 \\
\hline
\end{tabular}




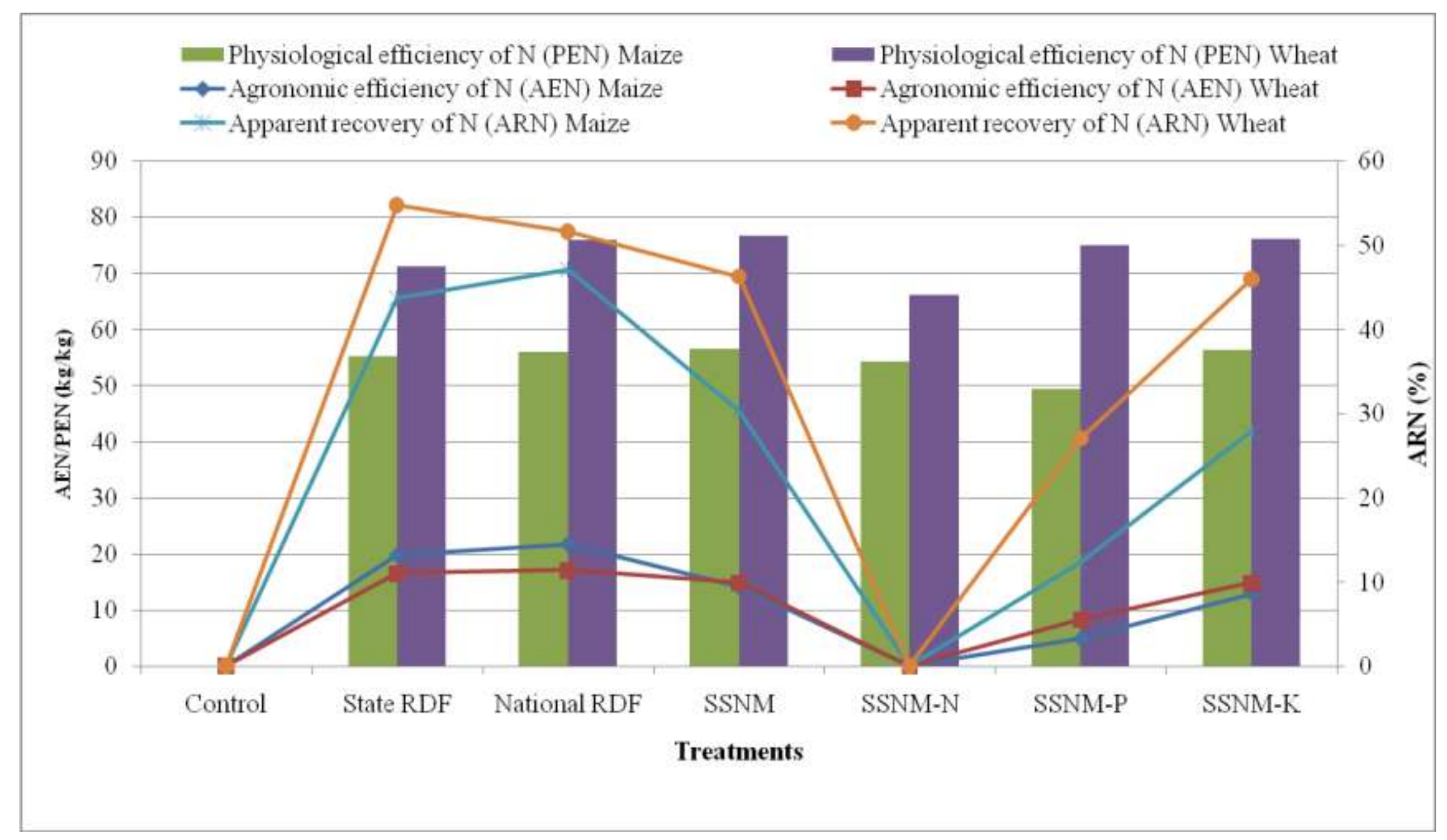

Fig.1 Nitrogen use efficiency of nutrient management practices in maize- wheat cropping system 
The higher yield reduction in the absolute control, omission of $\mathrm{N}$ and omission of $\mathrm{P}$ compared to omission of $\mathrm{K}$ and state-RDF and national-RDF. It might be due to low availability of nutrient in soil in respective omission plots could not meet the higher requirement of $\mathrm{N}$ and $\mathrm{P}$ for maize. Both the crops are nutrient exhaustive crops and respond well to better nutrient management. Similar finding of higher yield with SSNM compared to RDF were reported by Hargilas et al., (2017) and Jat et al., (2018) which might be due to availability of nutrient as per crop demand and indigenous nutrient supplying capacity of soil.

\section{Economics}

Yield was reflected directly to economics of cropping system (Table 4). Consistently higher gross and net returns were obtained from balanced application of nutrient through SSNM practice. The maximum gross return (Rs 148547/ha) was recorded under SSNM followed by SSNM-K and significantly higher over rest treatments. It was significantly reduced in tune of $51.39,41.18,28.32,18.32$ and $10.97 \%$ from absolute control, SSNM-N, SSNM-P, state-RDF and national-RDF, respectively. Similarly, maximum net return (Rs 104387/ha) was obtained in SSNM practice followed by SSNM-K which was significantly reduced in the tune of 62.33, $54.10,35.17,24.73$ and $16.71 \%$ from absolute control, SSNM-N, SSNM-P, state-RDF and national-RDF, respectively. The maximum $\mathrm{B}: \mathrm{C}$ ratio (2.36) was recorded in SSNM practice which was reduced in the tune of 49.15, 48.73, 26.27, 22.03 and 18.64\% from absolute control, SSNM-N, SSNM-P, state $\mathrm{RDF}$ and national RDF, respectively. The omission of $\mathrm{N}$ was reduced higher $\mathrm{B}: \mathrm{C}$ ratio compared to omission of P. It might be cleared that lower yield of cropping system in omitted plots was reflected directly to economics of cropping. Higher crop yields under SSNM based on nutrient experit ${ }^{\circledR}$ decision support tool resulted in higher net returns in maizewheat cropping system due to balanced application of nutrients at right time which leading to higher nutrient use efficiency (Jat et al., 2016). Sapkota et al., (2014) also reported significantly higher net returns from wheat production under SSNM approach compared to RDF and FFP.

\section{Nitrogen use efficiency}

Nitrogen use efficiency of the cropping system was influenced by different nutrient management practices (Fig. 1). Agronomic nitrogen use efficiency $\left(\mathrm{AE}_{\mathrm{N}}\right)$ of both the crops recorded highest under national RDF compared to other practice. It might be due to low dose of nitrogen in national RDF compared to SSNM. Agronomic nitrogen use efficiency was lowest recorded in omission of $\mathrm{N}$ and it was also recorded lower in omission of $\mathrm{P}$ and omission of $\mathrm{K}$ treatments. Physiological nitrogen use efficiency $\left(\mathrm{PE}_{\mathrm{N}}\right)$ of both the crops recorded highest under SSNM followed by SSNM-K and it decreased with omission of $\mathrm{N}$ and omission of $\mathrm{P}$. The higher physiological nitrogen efficiency under SSNM-K was showed the nitrogen uptake higher due to balanced availability of $\mathrm{K}$ in soil. Apparent nitrogen recovery (ANR\%) of maize was recorded highest under national RDF followed by state RDF and SSNM and it decreased in the omission of SSNM-P and SSNM-K. Whereas, apparent nitrogen recovery (ANR) of wheat was recorded highest with state RDF followed by national RDF and SSNM and it was decreased highest with omission of $\mathrm{P}$. It might be due to lesser availability of $\mathrm{N}$ to plant in unbalanced availability of $\mathrm{N}$ : P in soil. SSNM approach ensures that all limiting crop nutrients are applied in right dose and at right time (Hargilas et al., 2017) leading to higher nutrient use efficiency (Jat et al., 2016). 
Overall, the SSNM based nutrient management resulted in highest crop productivity and profitability of maize-wheat cropping system over state-RDF and national$\mathrm{RDF}$ in the system. The maximum reduction in growth, productivity and profitability of both the crop due to omission of $\mathrm{N}$ highlighted the significance of $\mathrm{N}$ application to maize and wheat that proved is to be the most limiting nutrient for maize and wheat over other nutrients. In nutshell, the SSNM approach rationalized the optimum nutrient use over recommended fertilizer use to make maizewheat cropping system more profitable and sustainable.

\section{References}

Dass, A., Suri, V. K. and Choudhary, A. K. 2014. Site-specific nutrient management approaches for enhanced nutrient-use efficiency in agricultural crops. Research and Reviews: Journal of Crop Science and Technology, 3(3):1-6.

Gomez K A and Gomez A A. 1984. Statistical Procedures for Agricultural Research. John Willley and Sons, New York.

Hargilas. 2016. Evaluation of site-specific nutrient management approach in transplanted rice under sub-humid condition of Rajasthan. Journal of Plant Development Sciences 8 (1): 3336.

Hargilas, Singh, A.K., Jat, S.L., Rokadia, P.K. and Kumar, Arvid, 2017. Response of maize (Zea mays) hybrids to nutrient management practices for enhancing productivity and profitability under sub-humid condition of Southern Rajasthan. Indian Journal of Agronomy 62 (3):326-331.

Jat, H.S., Jat, R.K., Singh, Yadvinder, Parihar, C.M., Jat, S.L., Tetarwal, J.P., Sidhu, H.S., Jat, M.L., 2016. Nitrogen management under conservation agriculture in cereal-based systems, Indian Journal of Fertilizer, 12(4):7691.

Jat, M.L., Saharawat, Y.S., and Gupta, R., 2011. Conservation agriculture in cereal systems of southern Asia nutrient perspectives. Karnataka journal of Agricultural Sciences, 24(1):100-105.

Jat, M.L., Satyanarayana, T., Majumdar, K., Parihar, C.M., Jat, S.L., Tetarwal, J.P., Jat, R.K. and Saharawat, Y.S. 2013. Fertiliser best management practices for maize systems. Indian Journal of Fertilizers 9(4): 80-94.

Jat, R.D., Jat, H.S., Nanwal, R.K., Yadav, A.K., Anil-Bana, Choudhary, K.M., Kakraliya, S.K., Sutaliya, J.M., Tek B. Sapkota, M.L. Jat, 2018.Conservation agriculture and precision nutrient management practices in maize-wheat system: Effects on crop and water productivity and economic profitability. Field Crops Research 222:111-120.

Rao K V. 2014. Research themes - Sitespecific integrated nutrient management for sustainable rice production and growth. Rajendranagar, Hyderabad, India: Rice Knowledge Management Portal (RKMP), Directorate of Rice Research.

Sapkota, T.B., Majumdar, K., Jat, M.L., Kumar, A., Bishnoi, D.K., Mcdonald, A.J., Pampolino, M., 2014. Precision nutrient management in conservation agriculture based wheat production of North-west India: Profitability, nutrient use efficiency and environmental footprint. Field Crops Research, 155:233-244.

Satyanarayana T, Majumdar K, Pampolino M, Johnston A M and Jat M L. 2013. Nutrient ExpertTM: A tool to optimize nutrient use and improve productivity 
of maize. Better Crops South Asia, 97(1): 21-24.

Satyanarayana, T., Majumdar, K., Pampolino, M., Johnston, A.M., Jat, M.L., Kuchanur, P., Sreelatha, D., Sekhar, J.C., Kumar, Y., Maheswaran, R., 2012. Nutrient Expert $($ : A tool to optimise nutrient use and improve productivity of maize. Better CropSouth Asia 6 18-21.

Stewart, W. M. 2002. News \& Views-A regional Newsletter. Potash and Phosphate Institute (PPI), USA and the Potash and Phosphate Institute of Canada (PPIC), p 2.

\section{How to cite this article:}

Hargilas. 2019. Response of Nutrient Omission on Growth, Productivity and Profitability of Maize (Zea mays)-Wheat (Triticum aestvum L) Cropping System in Southern Rajasthan. Int.J.Curr.Microbiol.App.Sci. 8(10): 1522-1532. doi: https://doi.org/10.20546/ijcmas.2019.810.177 